\title{
PENGARUH PERLETAKAN FONDASI PADA LERENG TERHADAP ANGKA AMAN
}

\author{
Reki Arbianto \\ Program Studi Teknik Sipil Fakultas Teknik Universitas Tunas Pembangunan Surakarta \\ rekiarbianto@gmail.com \\ Erni Mulyandari \\ Program Studi Teknik Sipil Fakultas Teknik Universitas Tunas Pembangunan Surakarta \\ erni.mulyandari@gmail.com
}

\begin{abstract}
Abstrak
Fondasi merupakan bagian yang sangat penting pada struktur bangunan, karena fondasi memikul beban struktur diatasnya. Perletakan fondasi pada lereng akan mempengaruhi kestabilan lereng itu sendiri, oleh karena itu perletakan fondasi menjadi sangat penting. Apabila lereng longsor fondasi akan runtuh begitu juga struktur di atasnya, seringkali kegagalan struktur akan menelan korban jiwa. Pada Analisis ini akan membahas keamanan lereng pada suatu struktur jalan dimana fondasi terletak pada lereng tersebut. Analisis numerik menggunakan bantuan software Slope/ $W$ dengan data tanah hasil pemboran inti. Data kohesi tanah merupakan hasil konversi dari nilai N-SPT. Berdasarkan perhitungan dapat diketahui bahwa perletakan fondasi pada tanah keras menghasilkan angka aman yang lebih besar dibandingkan dengan perletakan fondasi ada tanah lunak/tidak padat.
\end{abstract}

Kata kunci: Lereng, angka aman, fondasi, Slope/W

\begin{abstract}
The foundation is a very important part of the structure of the building, because the foundation carries the structural loads above it. Laying down the foundation on the slope will affect the stability of the slope, therefore placement of the foundation becomes very important. If the slope of the landslide foundation will collapse as well as the structure above it, often structural failure will cost lives. This analysis will discuss the safety of slopes on a road structure where the foundation is located on the slope. Numerical analysis uses the help of the Slope / W software with soil drilling data. Data on soil cohesion is the result of a conversion from the N-SPT value. Based on the calculation it can be seen that the laying of the foundation on hard soil produces a greater safe number compared to the laying of the foundation with soft / non-dense soil.
\end{abstract}

Keywords: slope, safety factor, fondation, Slope/W

\section{PENDAhuluan}

Infrastruktur jalan merupakan instrument yang sangat penting bagi kemajuan suatu daerah. Pembangunan jaringan jalan akan meningkatkan pertumbuhan ekonomi di sekitarnya. Analisis Stabilitas Lereng ini dilakukan untuk yang tepat.
Perencanaan Peningkatan Jalan Menuju Telaga Sarangan, Magetan, Jawa Timur. Hal ini dilakukan karena daerah pembangunan jalan akan melewati lereng, sehingga perlu analisis lebih lanjut terutama untuk perletakan fondasi 
Lokasi penyelidikan berada di Magetan, Jawa

Timur. Sket Lokasi Pengujian ditunjukkan pada

Gambar 1 sebagai berikut:

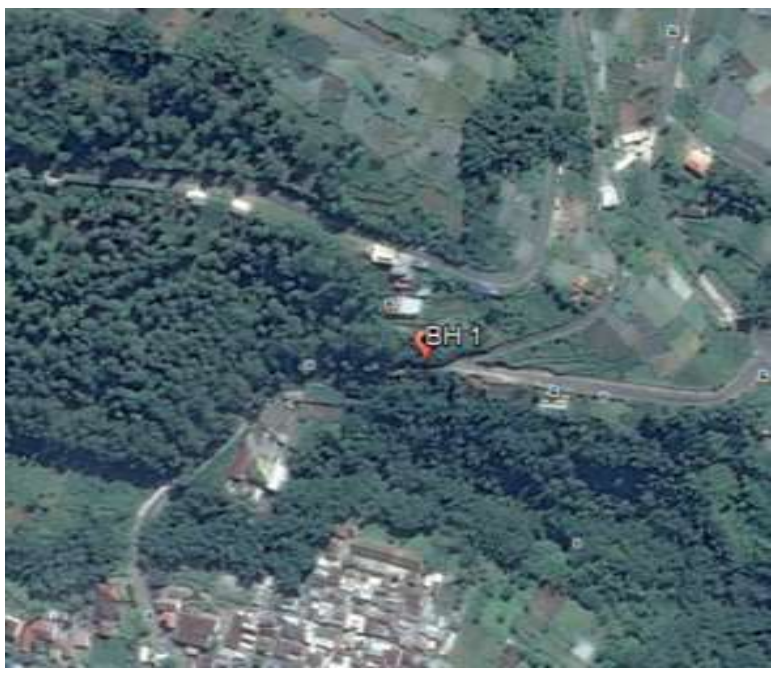

Gambar 1. Lokasi Penyelidikan

\section{LANDASAN TEORI}

\subsection{Analisis Stabilitas Lereng}

Analisis stabilitas lereng umumnya didasarkan pada konsep keseimbangan plastis batas (limit plastic ekuilibrium). Maksud dari analisis stabilitas adalah untuk mengetahui faktor aman dari bidang longsor yang potensial. Faktor aman didefinisikan sebagai nilai banding antara gaya yang menahan dan gaya yang menggerakkan. (Hardiyatmo, 2012)

$$
S F=\frac{\tau}{\tau_{d}}
$$

dengan :

$\mathrm{SF}=$ Faktor aman

$\tau=$ tahanan geser maksimum $\left(\mathrm{kN} / \mathrm{m}^{2}\right)$

$\tau_{\mathrm{d}}=$ tahanan geser yang terjadi $\left(\mathrm{kN} / \mathrm{m}^{2}\right)$

Bowles (1984) merekomendasikan kategori faktor aman sebagai berikut :

Tabel 1. Rekomendasi nilai SF lereng

\begin{tabular}{lc}
\hline \multicolumn{1}{c}{ SF } & Keruntuhan \\
\hline $\mathrm{SF}<1.07$ & Biasa terjadi \\
$1.07<\mathrm{SF}<1.25$ & Pernah terjadi \\
$\mathrm{SF}>1.25$ & Jarang terjadi \\
\hline
\end{tabular}

SNI 8460-2017 merekomendasikan kategori faktor aman sebagai berikut :

Tabel 2. Rekomendasi nilai SF lereng

\begin{tabular}{lc}
\hline \multicolumn{1}{c}{$\begin{array}{c}\text { Kondisi lereng } \\
\text { batuan }\end{array}$} & $\begin{array}{c}\text { Rekomendasi nilai } \\
\text { faktor keamanan }\end{array}$ \\
\hline $\begin{array}{l}\text { Kondisi lereng } \\
\text { permanen } \\
\text { Kondisi sementara }\end{array}$ & 1.5 \\
\hline
\end{tabular}

Metode perhitungan gaya-gaya yang bekerja pada bidang longsor telah dikembangkan beberapa peneliti antara lain : Bishop's rigorous, Spencer's, Sarma's dan Morgenstern-Price yang memberikan cara yang lebih kompleks dengan memperhitungkan kesetimbangan gaya momen.

Adapun gaya-gaya yang bekerja pada irisan bidang longsor ditunjukkan pada Gambar 2 . Sebagai berikut:
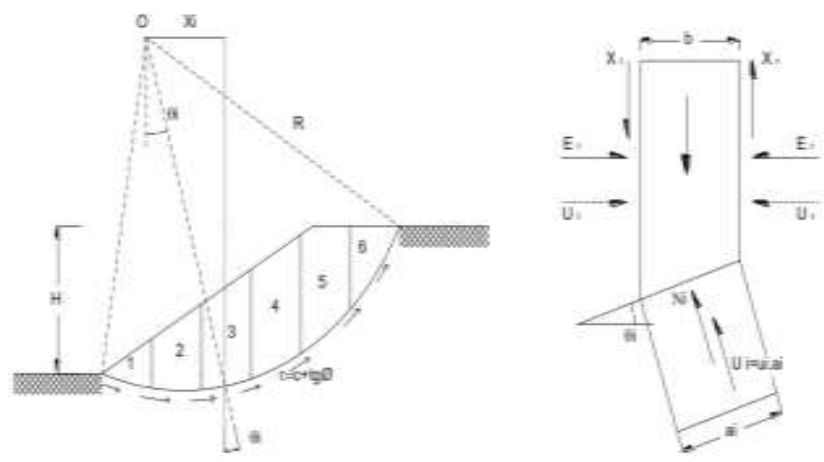

Gambar 2. Gaya yang bekerja pada irisan bidang longsor

\subsection{Parameter Kuat geser}

Parameter kuat geser tanah terdiri dari kohesi (c) dan sudut gesek internal ( $\varphi$ ). Menurut 
Mohr-Coulumb (1776) dalam Hardiyatmo (2012) memberikan Persamaan umum sebagai berikut:

$$
\tau=c+\sigma \operatorname{tg} \varphi
$$

dengan :

$$
\begin{array}{ll}
\tau & =\text { kuat geser tanah }\left(\mathrm{kN} / \mathrm{m}^{2}\right) \\
\mathrm{c} & =\text { kohesi tanah }\left(\mathrm{kN} / \mathrm{m}^{2}\right) \\
\varphi & =\text { sudut gesek dalam }\left({ }^{\circ}\right) \\
\sigma & =\text { teg. normal pada bid.runtuh }\left(\mathrm{kN} / \mathrm{m}^{2}\right)
\end{array}
$$

Penentuan kuat geser tanah untuk setiap lapisan ditentukan dengan korelasi nilai undrained strength terhadap nilai SPT. Menurut Terzaghi nilai $\mathrm{Cu}$ dapat diperkirakan dengan korelasi seperti Gambar 2 di bawah ini. Nilai konservatif untuk $\mathrm{Cu}$ terhadap $\mathrm{N}$ adalah:

$$
\mathrm{Cu}=\frac{2}{3} \mathrm{~N}
$$

dengan :

$\mathrm{C}_{\mathrm{u}} \quad=$ kuat geser undrained $\left(\mathrm{t} / \mathrm{m}^{2}\right)$

$\mathrm{N} \quad=\mathrm{N}-\mathrm{SPT}$

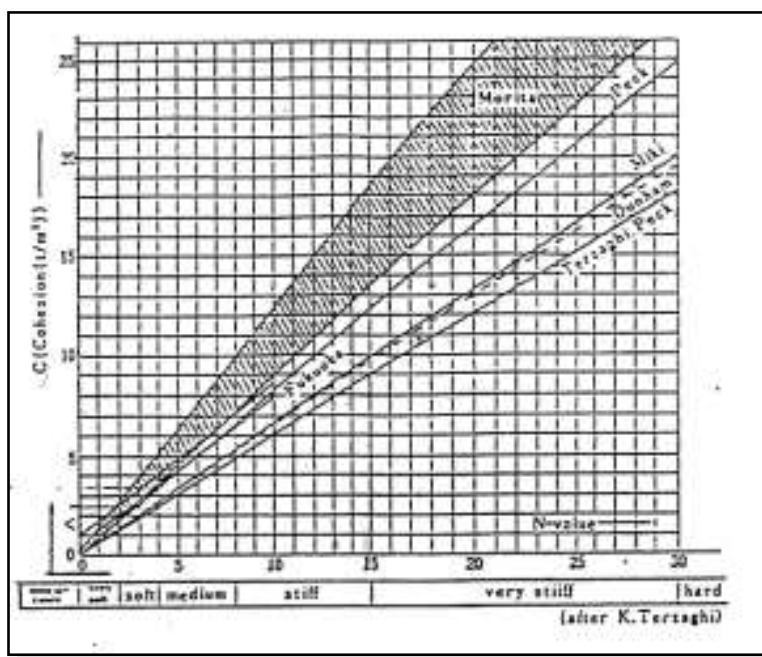

Gambar 3. Korelasi antara kohesi dan N-SPT (Terzaghi, 1943)

\section{METODE PENELITIAN}

\subsection{Pengumpulan Data}

a) Data Tanah

Data yang digunakan adalah hasil pemboran inti sedalam $30 \mathrm{~m}$, Adapun ringkasan lapisan tanah adalah sebagai berikut:

Tabel 3. Tipe Lapisan Tanah

\begin{tabular}{cccc}
$\begin{array}{c}\text { No. } \\
\text { Lapisan }\end{array}$ & $\begin{array}{c}\text { Unit Weight } \\
(\mathrm{kN} / \mathrm{m} 3)\end{array}$ & $\begin{array}{c}\text { Cohesion } \\
(\mathrm{kPa})\end{array}$ & $\begin{array}{c}\text { Phi } \\
\left({ }^{\circ}\right)\end{array}$ \\
\hline 1 & 17 & 90 & 0 \\
2 & 18 & 100 & 0 \\
3 & - & - & - \\
\hline
\end{tabular}

b) Geometri Lereng

Adapun data geometri lereng yang dipakai adalah sebagai berikut:

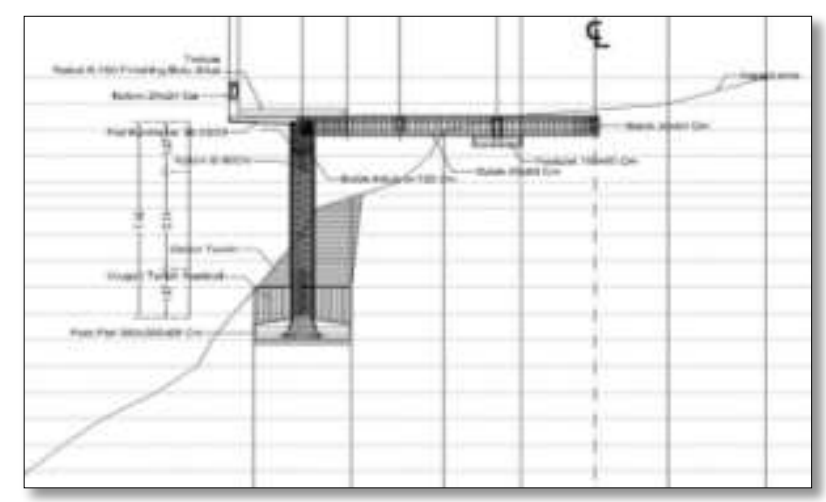

Gambar 4. Geometri Lereng Tipe 1

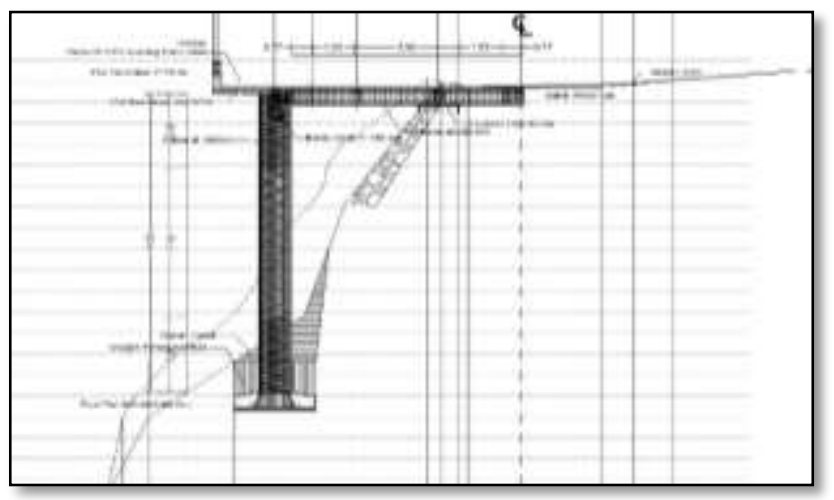


Gambar 5. Geometri Lereng Tipe 2

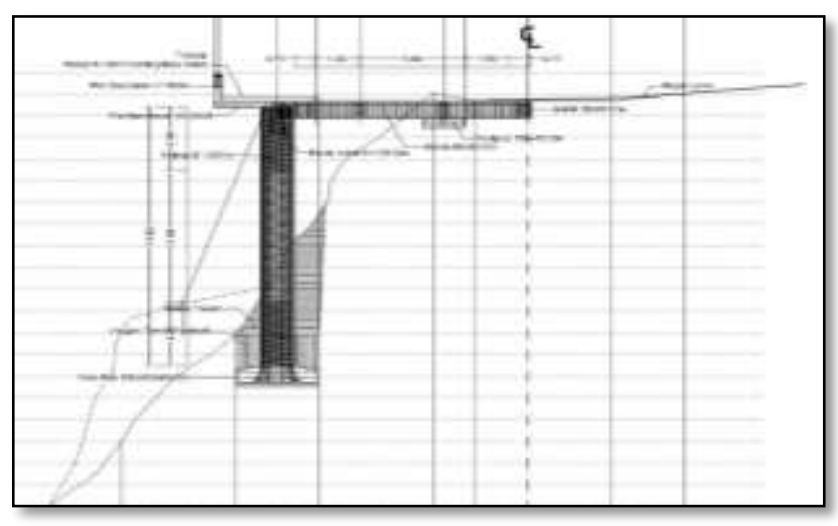

Gambar 6. Geometri Lereng Tipe 3

c) Beban Fondasi

Beban-beban yang di terima fondasi adalah sebagai berikut:

Tabel 4 Beban Fondasi

\begin{tabular}{clc}
\hline No. & \multicolumn{1}{c}{ Uraian } & Beban $(\mathrm{kg})$ \\
\hline 1 & Beban Struktur & 360.074 \\
2 & Beban Tanah & 24.480 \\
3 & Beban Fondasi & 23.040 \\
\hline
\end{tabular}

d) Simulasi Numerik

Analisis stabilitas lereng dengan Slope/ $W$ dengan masukan dari parameter hasil uji bor dalam. Pada analisis ini akan melihat perubahan angka aman dari beberapa model perletakan fondasi.

\section{ANALISIS}

Berdasarkan simulasi numeris didapatkan pemodelan dalam program sebagai berikut:

\subsection{Lereng Tipe 1}

a) Model 1.a Lereng asli (tanpa beban fondasi)

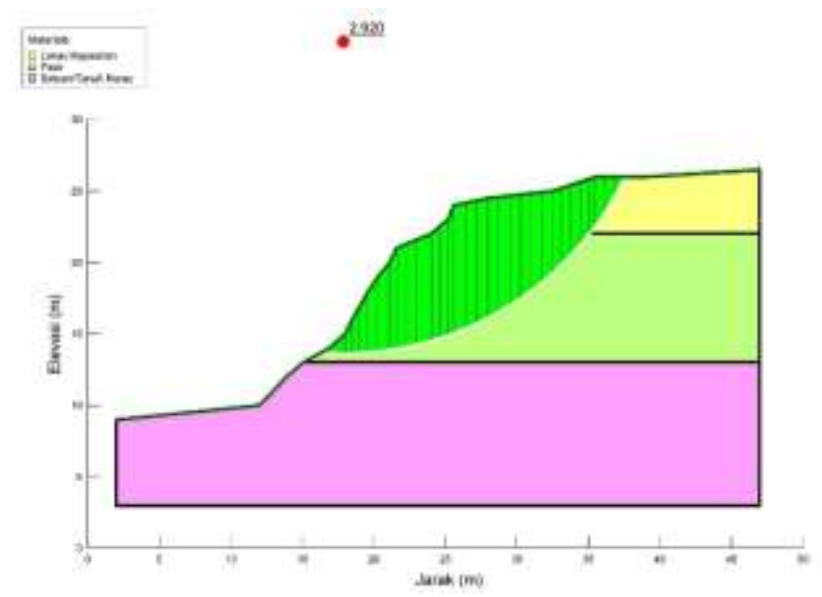

Gambar 7. Model 1.a

Gambar 7 menunjukkan hasil running Slope/W pada model 1.a dengan angka aman sebesar 2.920. Artinya lereng masih aman terhadap, Garis longsor tidak dapat menembus lapisan tanah keras (bedrock).

b) Model 1.b Lereng dengan fondasi pada lapisan Pasir tidak padat

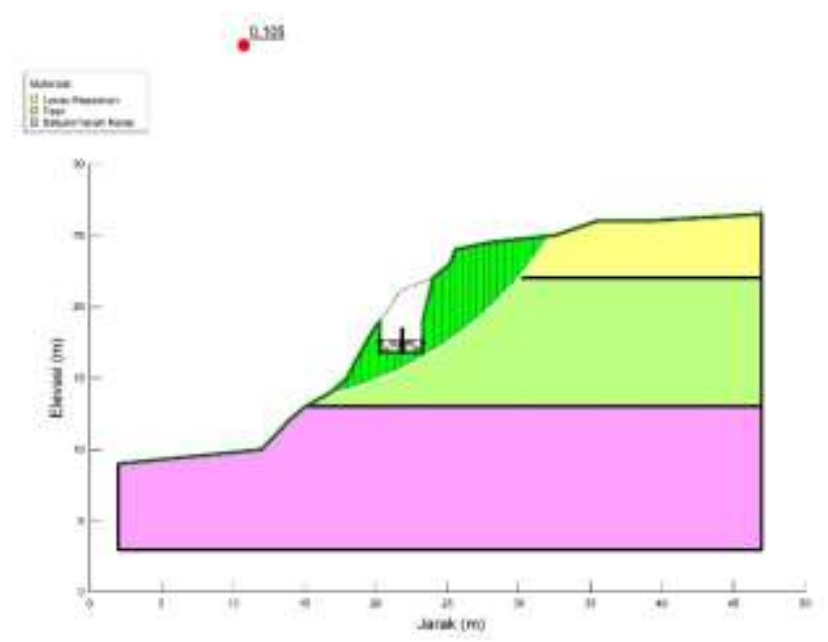

Gambar 8. Model 1.b

Gambar 8 menunjukkan hasil running Slope/W pada model 1.b dengan angka aman sebesar 0.105 mengalami penurunan yang signifikan dari model 1.a. Artinya lereng dalam kondisi tidak aman. Hal ini disebabkan adanya tambahan beban fondasi. Selain itu perletakan fondasi tidak pada lapisan tanah keras 
(Bedrock). Sehingga sangat mungkin Gambar 10 menunjukkan hasil running mengalami kelongsoran.

Slope/w pada model 2.a dengan angka aman

c) Model 1.c Lereng dengan fondasi pada lapisan tanah keras sebesar 2.028. Artinya lereng aman terhadap longsoran.

b) Model 2.b (fondasi pada pasir tidak padat)

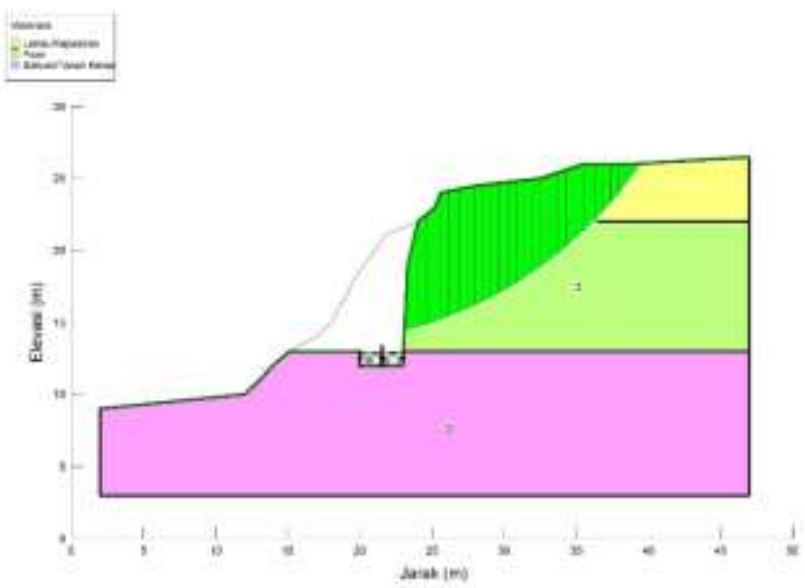

Gambar 9. Model 1.c

Gambar 9 menunjukkan hasil running Slope/W pada model 1.c dengan angka aman sebesar 2.390 mengalami peningkatan yang signifikan dari model 1.b. Artinya lereng dalam kondisi aman. Hal ini disebabkan karenanya perletakan fondasi pada lapisan tanah keras (Bedrock). Sehingga aman terhadap kelongsoran.

\subsection{Lereng Tipe 2}

a) Model 2.a Lereng asli (tanpa beban fondasi)

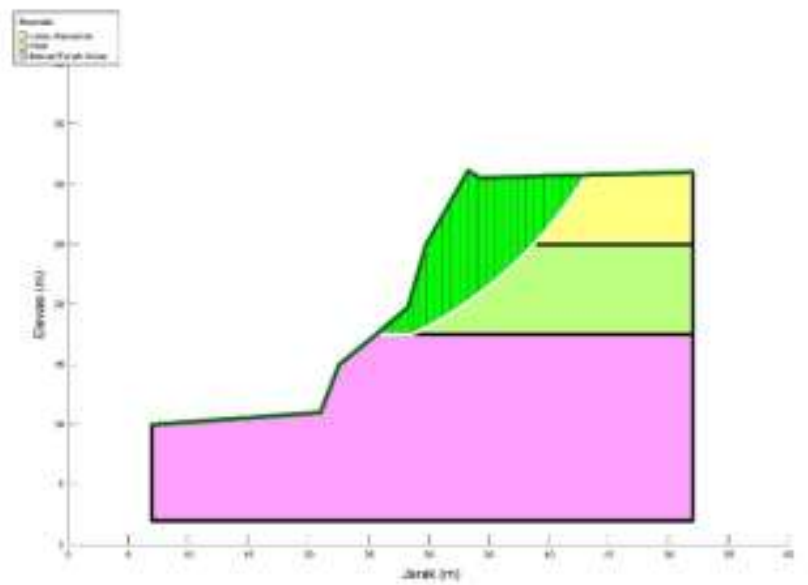

Gambar 10. Model 2.a

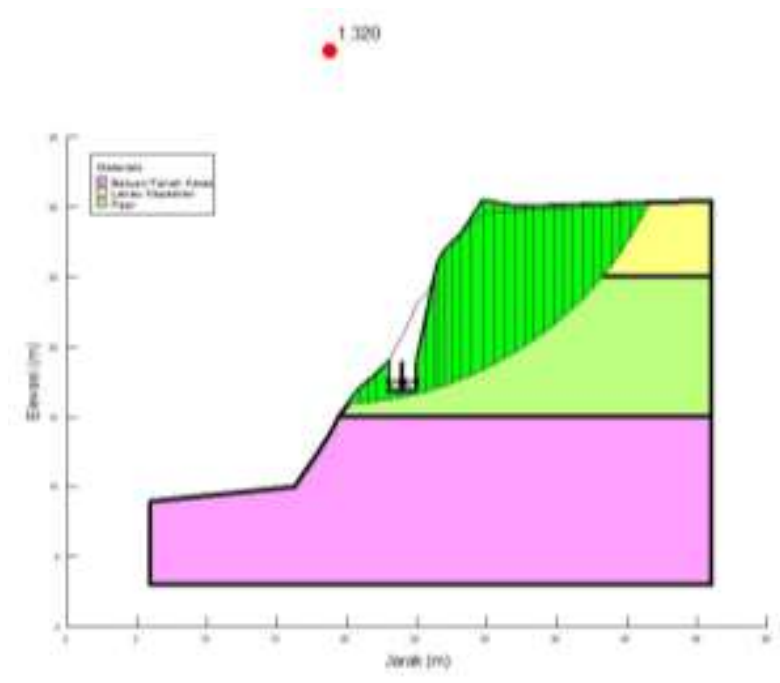

Gambar 11. Model 2.b

Gambar 11 menunjukkan pemodelan perletakan fondasi pada tanah yang tidak padat menghasilkan angka aman sebesar 1.320 artinya lereng tidak aman

c) Model 2.c Lereng dengan fondasi pada lapisan tanah keras

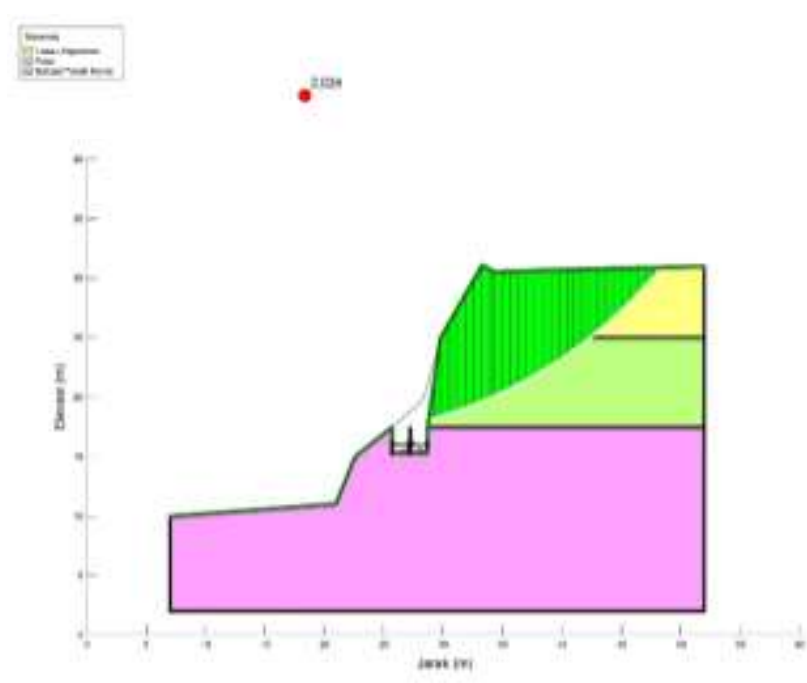

Gambar 12. Model 2.c 
Gambar12 menunjukkan hasil running Slope/w pada model 2.c dengan angka aman sebesar 2.034. Artinya lereng dalam kondisi aman. Hal ini disebabkan karenanya perletakan fondasi pada lapisan tanah keras (Bedrock). Sehingga aman terhadap kelongsoran.

\subsection{Lereng Tipe 3}

a) Model 3.a (tanpa beban fondasi)

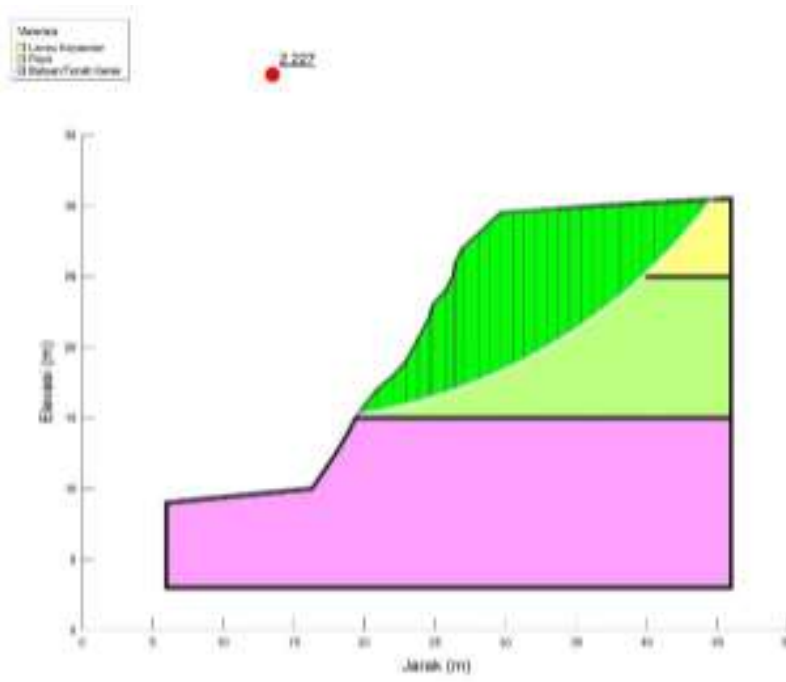

Gambar 13. Model 3.a

Gambar 13 menunjukkan hasil running Slope/W pada model 3.a dengan angka aman sebesar 2.227. Artinya lereng dalam kondisi aman.

b)Model 3.b (fondasi pada pasir tidak padat)

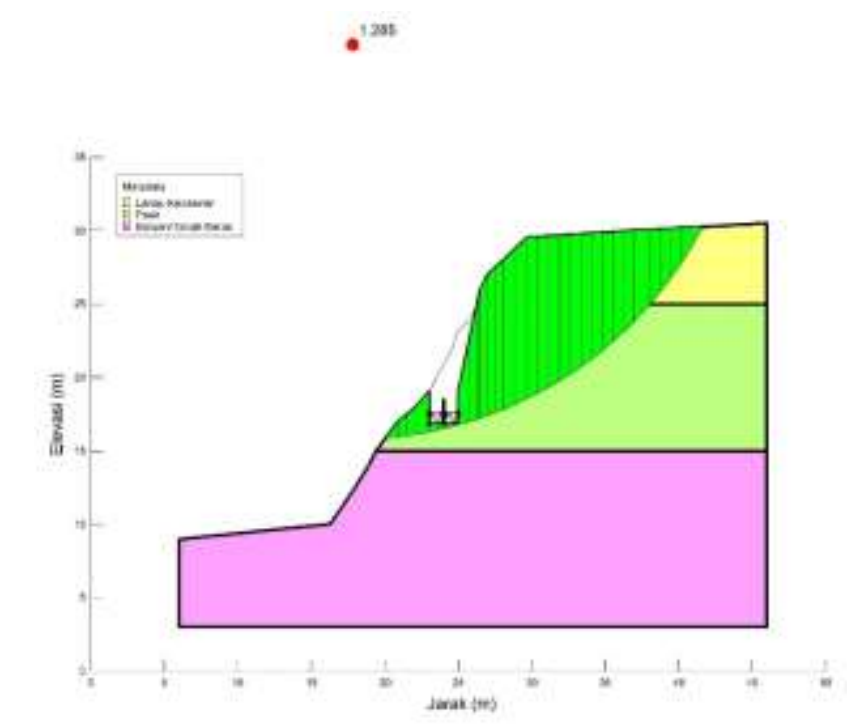

Gambar 14. Model 3.b

Gambar 14 menunjukkan hasil running Slope/ $W$ pada model 3.b dengan angka aman sebesar 1.285, artinya lereng dalam kondisi tidak aman. Karena perletakan fondasi yang kurang sesuai. Oleh karena tanah tidak mampu menahan beban dan mengakibatkan longsor.

d) Model 3.c (fondasi pada lapisan tanah keras) issas

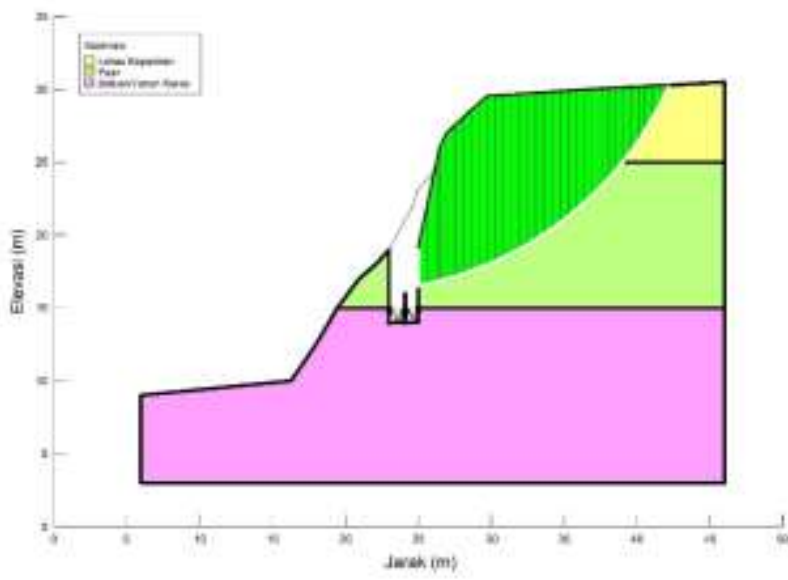

Gambar 15. Model 3.c

Gambar 15 menunjukkan hasil running Slope/W pada model 3.c dengan angka aman sebesar 1.905. SF mengalami peningkatan yang signifikan dari model 10. Artinya lereng dalam kondisi aman. Hal ini disebabkan karenanya 
perletakan fondasi pada lapisan tanah keras

(Bedrock). Sehingga aman terhadap kelongsoran.

Adapun rekapitulasi hasil pemodelan dan Analisis stabilitas lereng menggunakan Program Slope/w adalah sebagai berikut:

Tabel 5 Rekapitulasi Analisis Pemodelan

\begin{tabular}{|c|c|c|c|c|}
\hline No & $\begin{array}{c}\text { Type } \\
\text { Pemodelan }\end{array}$ & Uraian & $\begin{array}{l}\text { Safety } \\
\text { Factor }\end{array}$ & Keterangan \\
\hline 1 & Model 1.a & $\begin{array}{l}\text { Lereng Tipe } 1 \\
\text { tanpa fondasi }\end{array}$ & 2.920 & Aman \\
\hline 2 & Model 1.b & $\begin{array}{l}\text { Lereng Tipe } 1 \\
\text { Fondasi pada } \\
\text { tanah } \\
\text { lunak/tidak } \\
\text { padat }\end{array}$ & 0.105 & Tidak aman \\
\hline 3 & Model 1.c & $\begin{array}{l}\text { Lereng Tipe } 1 \\
\text { Fondasi pada } \\
\text { tanah keras }\end{array}$ & 2.390 & Aman \\
\hline 4 & Model 2.a & $\begin{array}{l}\text { Lereng Tipe } 2 \\
\text { tanpa fondasi }\end{array}$ & 2.028 & Aman \\
\hline 5 & Model 2.b & $\begin{array}{l}\text { Lereng Tipe } 2 \\
\text { Fondasi pada } \\
\text { tanah } \\
\text { lunak/tidak } \\
\text { padat }\end{array}$ & 1.320 & Tidak Aman \\
\hline 6 & Model 2.c & $\begin{array}{l}\text { Lereng Tipe } 2 \\
\text { Fondasi pada } \\
\text { tanah keras }\end{array}$ & 2.034 & Aman \\
\hline 7 & Model 3.a & $\begin{array}{l}\text { Lereng Tipe } 3 \\
\text { tanpa fondasi }\end{array}$ & 2.227 & Aman \\
\hline 8 & Model 3.b & $\begin{array}{l}\text { Lereng Tipe } 3 \\
\text { Fondasi pada } \\
\text { tanah } \\
\text { lunak/tidak } \\
\text { padat }\end{array}$ & 1.285 & Tidak aman \\
\hline 9 & Model 3.c & $\begin{array}{l}\text { Lereng Tipe } 3 \\
\text { Fondasi pada } \\
\text { tanah keras }\end{array}$ & 1.905 & Aman \\
\hline
\end{tabular}

Adapun perbandingan kenaikan angka aman pada masing-masing tipe lereng disajikan pada tabel sebagai berikut:

Tabel. 6. Perbandingan Angka Aman

\begin{tabular}{|c|c|c|c|}
\hline \multirow{2}{*}{ Pemodelan } & \multicolumn{2}{|c|}{ Angka aman } & \\
\cline { 2 - 4 } & $\begin{array}{c}\text { Perietakan pada } \\
\text { tanah lunak }\end{array}$ & $\begin{array}{c}\text { Perietakan pada } \\
\text { tanah keras }\end{array}$ & $\begin{array}{c}\text { Kenaikan } \\
\text { (\%) }\end{array}$ \\
\hline Model 1 & 0.105 & 2.39 & $>100 \%$ \\
\hline Model2 & 1.32 & 3.034 & $>100 \%$ \\
\hline Model3 & 1.285 & 1.905 & $48 \%$ \\
\hline
\end{tabular}

Untuk memperjelas kenaikan angka aman pada masing-masing model disajikan pada grafik sebagai berikut:

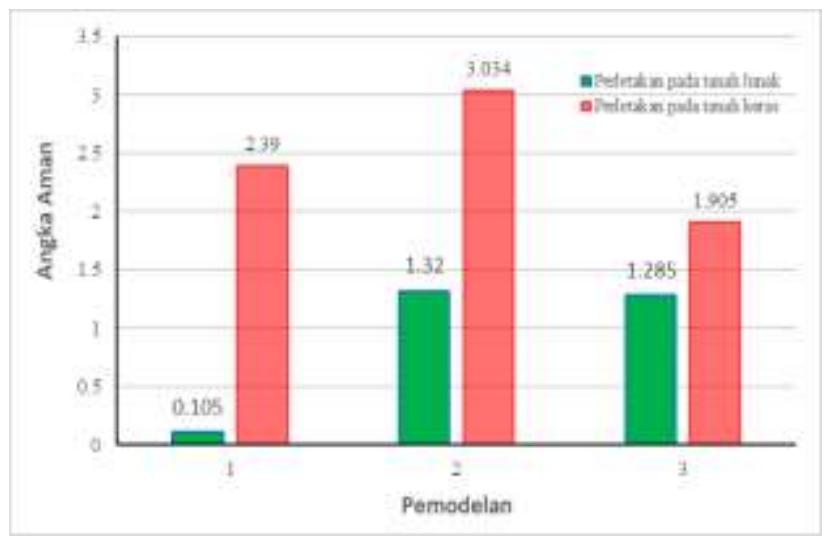

Gambar 16. Kenaikan Angka Aman

\section{KESIMPULAN/RINGKASAN}

Berdasarkan hasil analisis yang dilakukan dapat disimpulkan bahwa:

1. Fondasi sebaiknya diletakkan pada lapisan tanah keras untuk menghindari penurunan berlebih dan keruntuhan.

2. Angka aman meningkat signifikan dari letak fondasi pada tanah lunak/tidak padat ke lapisan tanah keras.

3.Pentingnya soil investigasi untuk mengetahui lapisan dan properties tanah.

\section{DAFTAR PUSTAKA}

Ambramson, Lee W et al., 2004, Slope Stability and Stabilization Methods, John

Bowles, Joseph E.,1989, Sifat-sifat Fisis dan Geoteknis Tanah, Erlangga, Jakarta. 
Das, Braja M.,2011, Principles of Foundation Engineering, Global Engineering, USA.

Geo-Slope Manual, 2008, An Engineering Methodology, Geo-Slope International Ltd, Canada.

Hardiyatmo, H.C.,2012, Mekanika Tanah I, Gadjah Mada University Press, Yogyakarta

Hardiyatmo, H.C.,2010, Mekanika Tanah II, Gadjah Mada University Press, Yogyakarta.

Hardiyatmo, H.C.,2012, Penanganan Tanah Longsor dan Erosi, Gadjah Mada University Press, Yogykarta.

Wiley and Sons, Inc, New York. ASTM, 2013, "Annual Books of ASMT Standard", ASTM, Easton. MD, USA.

Muntohar., Saputro., 2014, Pengaruh Kedalaman Muka Air Tanah Awal Terhadap Analisis Stabilitas Lereng Tak Jenuh, Seminar Nasional X, Teknik Sipil ITS, Surabaya.

Rahardjo, H, 1016, Application of Unsaturated Soil Mechanics to Open Pit Slope Stability, Australian Center for Geomechanics. Vol.42.

Rifa'i, 2011, Effect of Matric Suction Change on Unsaturated Soil Parameter in Slope Satability Analysis Due to Rainfall, Seminar Nasional-I-BMTTSSI- konteks 5; G15-G23.

Zaruba, Q. and Mencl, V., 1969, Landslides and Their Control, Elsevier, London, England. 